\title{
History, Impact of Soil Types on Stand Structure and Growth of the Dry Zone Mahogany (Khaya senegalensis (Desr.) A.Juss.) in Plantation in Benin (West Africa)
}

\author{
Akpona Tèwogbadé Jean Didier,", Idohou Rodrigue ${ }^{1}$, Assogbadjo Achille², Salako Kolawolé Valère ${ }^{1}$, \\ Glèlè Kakaï Romain ${ }^{1}$ \\ ${ }^{1}$ Laboratory of Biomathematics and Forest Estimations, Faculty of Agricultural Sciences, University of Abomey-Calavi, Benin \\ ${ }^{2}$ Laboratory of Applied Ecology, Faculty of Agronomic Sciences, University of Abomey-Calavi, Benin
}

Copyright $\bigcirc 2016$ by authors, all rights reserved. Authors agree that this article remains permanently open access under the terms of the Creative Commons Attribution License 4.0 International License

\begin{abstract}
The reported declines in populations of several native species have biological, cultural and economic implications as cattle and illegal logging. To understand factors supporting endangered species conservation and management in Benin, we focused on plantations of dry zone Mahogany (Khaya senegalensis (Desr.) A.Juss.) in sudano-guinean zone of Benin. This study illustrates how the dry zone mahogany is established in plantations in Benin. It discusses the challenges for its appropriate conservation and management in Benin.
\end{abstract}

Keywords $K$. senegalensis, Plantation, Conservation, Dendrometrics Parameters, Benin

\section{Introduction}

Benin is a moderate forest country where vegetation is savannah-dominated. According to FAO[12] (1999), the forest cover is estimated at 2,538,000 hectares, which represents $23 \%$ of the country total area. Despite this situation of limited forest resources, vegetation is still declining with an average of 70,000 hectares of natural forest lost each year (DGFRN [10], 2012). This forest decline is mainly due to high demography, agriculture and forest logging. At the same time, very few initiatives exist in the country as regards the establishment of the plantation of commercial timber species in the country. This situation mainly results from a lack of proper understanding of appropriate silvicultural practices for the most seen species among which is Khaya senegalensis (Desr.) A.Juss.

$K$. senegalensis (Desr.) A. Juss. is one of the most important Meliaceae timber species in Africa. It is distributed in Sudano-Zambezian and Sahelian regions. It is a multipurpose tree species. $K$. senegalensis (hereafter Khaya) is harvested as one of the best and the first- timber species exported from Africa early during the colonial era (Parren [21], 2003). It is a fodder species (Sinsin [25] et al. 1989) and is also used to cure several human diseases (Sokpon et Ouinsavi [26], 2002) as well as livestock diseases (Atawodi [6] et al. 2002). Because of its over-exploitation, the $11^{\text {th }}$ session of FAO Panel of experts on forest genetic resources identified the species as top priority species for FAO activities in Africa (FAO [13] 2004). However, few plantations have been set to provide local populations and most importantly the timber market with Khaya trees. It is only recently that the government of Benin has initiated some reforestation programmes with native species including Khaya to be implemented at local and national levels through the National Office of Wood. Therefore, actions towards setting healthy plantations are needed to support these programmes.

Reforestation is used to mitigate forest degradation and has been adopted by the country for many years. However, the methods often used do not meet expected targets. Plantations are often based on the use of exotic species with limited integration of local species that could contribute to biodiversity conservation.

Recent assessment of existing plantations revealed high tree mortality. This comes from the fact that current programs promote plantations of species without quality control of their behavior and types of substrate for a successful growth.

Khaya grows in a wide range of soil types (Robertson \& Rilley [23], 2002). The $\mathrm{pH}$ tolerance can range between neutral to very strongly acidic, though a neutral $\mathrm{pH}$ is more desirable. Although Khaya has been planted on different types of soils in Benin, it is still unclear how the impact of the soils types on the stand structure has been made. This is however important as it could guide in successful and long term reforestation program involving the species.

This study aims to: (1) highlight the importance of mahogany in reforestation programs in Benin; (2) assess the 
impact of soil types on the stand structure of the dry mahogany; (3) propose recommendations towards sustainable management of the dry mahogany in Benin.

\section{Methodology}

\subsection{Study Species and Area}

\subsubsection{Study Species}

Khaya is a native species of Benin listed in Red list of IUCN as vulnerable and endangered in Benin red list (Adomou [2] et al. 2011).

Khaya is still a highly prized wood (Dalziel [9] 1937; Gaoue \& Ticktin [15] 2007; Parren [21] 2003), and is illegally logged for timber and harvested by local people for many purposes. It is also harvested for its bark and foliage that increase low seeds and natural regeneration from the seed is poor. Khaya is reported as monoecious, insect pollinated and wind dispersed, with poor natural regeneration (Salim [24] et al. 2002; Joker \& Gamene [18] 2003).

Fulani use to harvest Khaya trees as one of the rare sources of fodder to feed their cattle in the Sudanian and Sudano-Guinean regions (Sinsin[25] et al. 1989; Gaoue \& Ticktin[16] 2009). The seedlings that emerge from this harsh system are subject to overgrazing and fire which constitute other challenging factors for their survival. Khaya plantations are found in Benin especially in the Sudano-Guinean zone where this study took place.

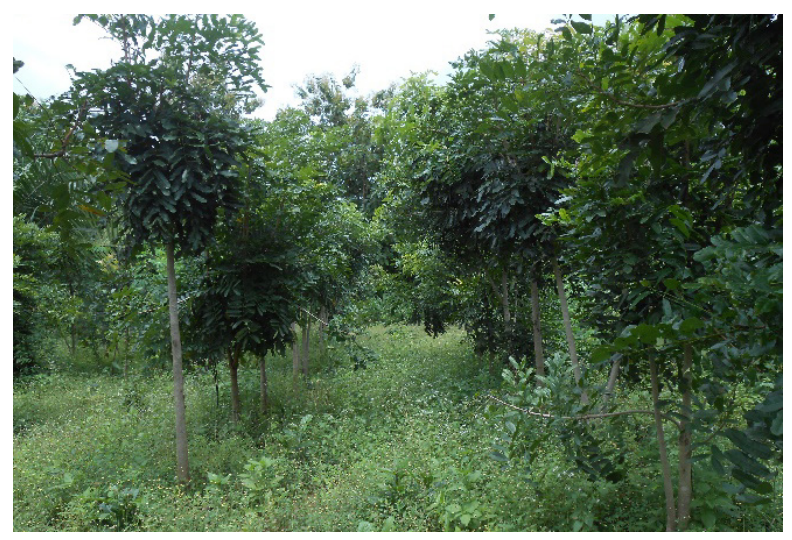

Figure 1. Two years plantation of $K$. senegalensis on ferralitic soil

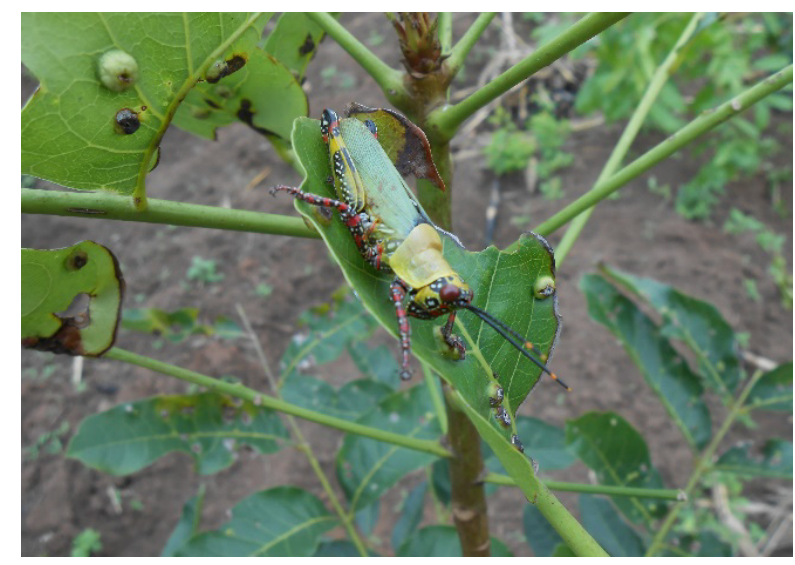

Figure 2. Zonocerus variegatus damage on KS terminal bud

\subsubsection{Study area}

The study was conducted in 2 degraded national forest located in Sudano-Guinean region where reforestation sites were established by the National Office of Wood of Benin (Figure 1). The Sudano-Guinean zone is located between the latitude $7^{\circ} 30-9^{\circ} 30 \mathrm{~N}$. The climate is subequatorial with a bimodal rainfall regime. The average rainfall is between 1100 and $1400 \mathrm{~mm}$. The two rainfall peaks tend to merge into one peak, thus a unimodal rainfall regime (Adjanohoun [1] et al. 1998, Akoègninou [4] 2004). Vegetation is dominated by Woodlands, savannah, semi-deciduous forest and gallery forest. The woodland has abundant species like Isoberlinia spp. Associated species include Monotes kerstingii and Uapaca togoensis. Berlinia grandiflora and Cola laurifolia are common in riparian forest. The dry forest dominated by Anogeissus leiocarpa also occurs and generally fringes the riparian forest. Parklands are dominated by Vitellaria paradoxa, Parkia biglobosa, Khaya senegalensis and Afzelia africana (Wezel \& Böcker[28] 2000). Beside the expansion of crop land, the traditional use of fuel is another important factor in the reduction of woodlands.

In the study area, two major groups of soils can be distinguished (Willaine \& Volkoff[29] 1967): (1) ferruginous soils covered by semi-deciduous forest, (2) vertisol in the depression of Lama covered by a particular dry type of semi-deciduous forest. 

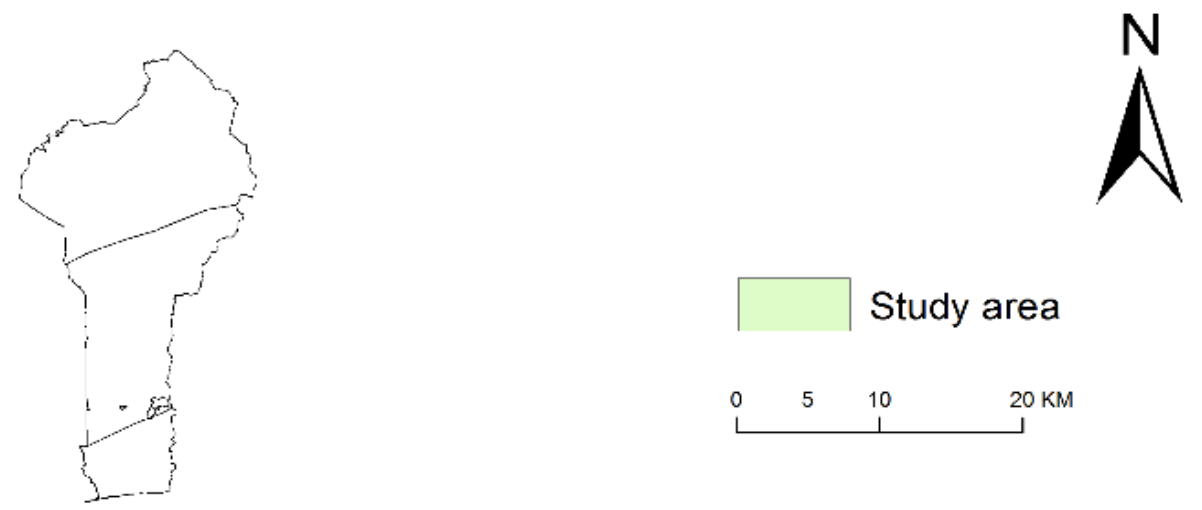

\section{Study area}
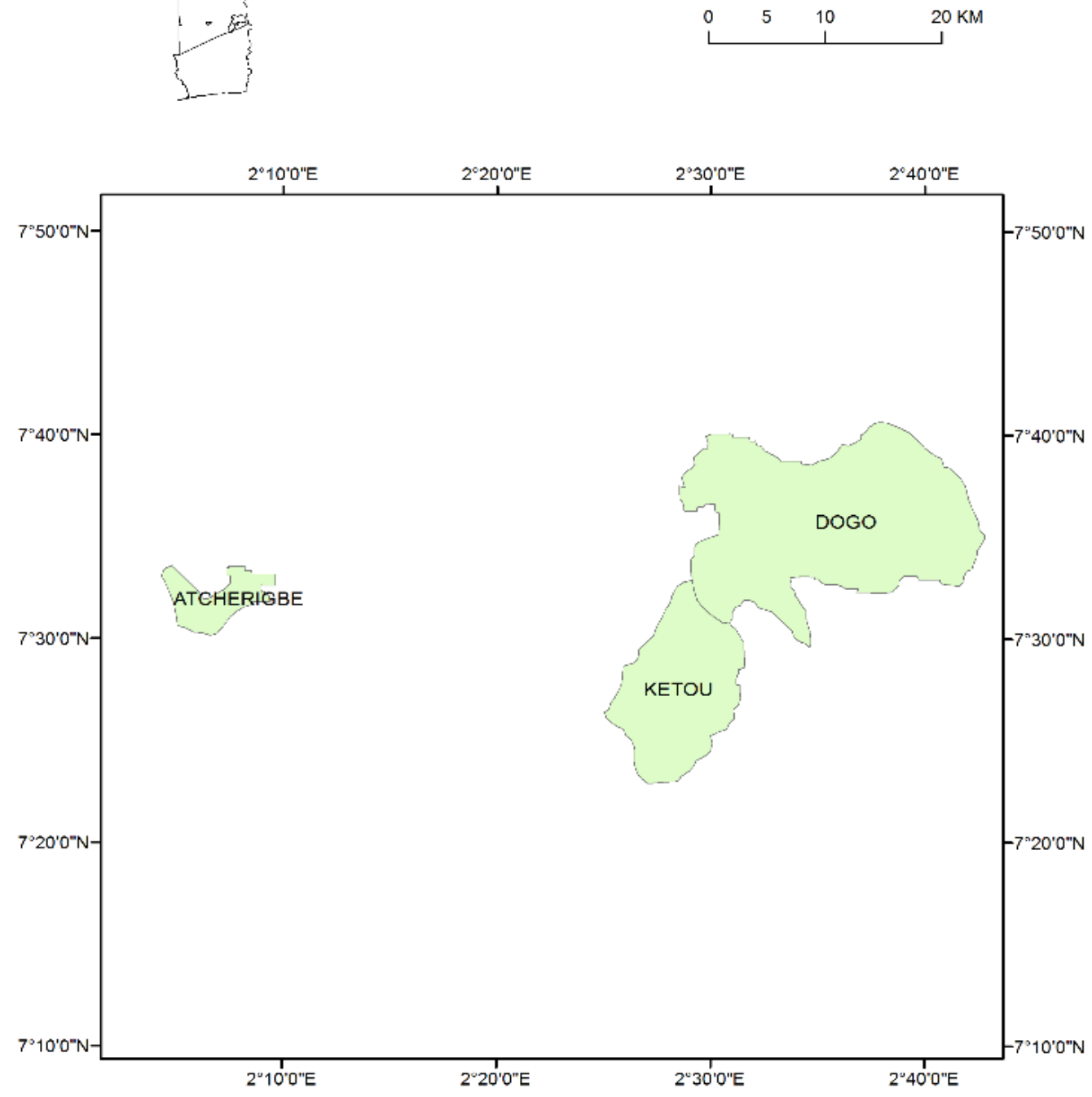

Figure 3. Map of the study area

\subsection{Data Collection}

The importance of Khaya in ONAB plantations was assessed by collecting information's on the total area reforested for main reforestation species for a period of 5 years. Data is collected from ONAB administration about the area (ha) planted each year between 2009 to 2013 with Tectona grandis (the most important alien species used in large scale reforestation in Benin) and Khaya (targeted as the most indigenous species that could be promoted in large scale reforestation in Benin).

Moreover, nine random plots of 1 ha (Djossa [7] et al. 2008) were established in the forests plantation and their geographic coordinates were recorded. The total sampled area in the forests ( $9 \mathrm{ha}$ ) represented $5 \%$ of the total surface covered by the reforestation surface in this zone. Within each one-ha plot, all individuals of Khaya were counted. In addition, collar diameter of all Khaya seedlings were measured as well as their total height. Moreover, the plantation age and the types of soil were recorded within each plot.

\subsection{Data Analysis}

Dendrometric parameters (density, total height, and basal diameter) were computed for the plantations for each type of 
soil. Two sample t-tests was performed (after checking for normality and homoscedasticity) and values were retained and used further for the computation of probability after 10000 permutation based on Manly (1997). This method was used because the homoscedasticity condition was not fulfilled. Further, the error bar plots were established in order to easily select the best soil structure that allows rapid growth of Khaya stems. Same analyses were done when only factor age was considered in order to assess the impact of age on mahogany plantation in southern Benin. All analyses were done in R 3.1.2 (R Development Core Team 2014).

\section{Results}

\subsection{History of $K$. senegalensis Plantation in Benin}

The promotion of native species started with colonial administration in 1935 with introduction of Khaya plantations in Benin. These plantations were established as experimental stands in different part of the country. Three types of plantations are distinguishable: test plantations (Toffo, Atchérigbé, Kandi, Kouandé, Tanguiéta); school plantations (Birni, Kouaba) and road plantations. Different sowing devices were used (square, staggered) with different spacing $(20 \mathrm{~m} \times 20 \mathrm{~m} ; 10 \mathrm{~m} \times 10 \mathrm{~m})$ and different combinations (pure or mixed plantations) with others species like (Tectona grandis, Afzelia Africana, Senna siamea) were tested.

The diver's reasons like attacks of shoot borer (Hypsipila robusta) on seedlings and saplings of Khaya (Figure 2) negatively impact it sustainable growth and can contribute to the failure of native species plantations. For this reason and according to the necessity of plantation establishment, between 1953 and 1959, great efforts were made in teak plantations, leading to the abandonment of indigenous species. Considering this, effort was made neither to better know the silviculture of this species nor to develop better management against this pest. For that reason and population increase and urbanization, many plantations have disappeared Examples include plantations of Guene (7ha) and road plantations of boulevard Saint-Michel, , Tori road, road of Dassa-Savalou and road of Tchatchou-Parakou.

Since then, exotic species were preferred in plantation with introduction of other species like Gmelina arborea. The biodiversity conservation strategy targets the reintroduction of native species in plantation. With project of Management of Forest and riverside lands (PGFTR in French) and National Office of Wood (ONAB in French) some plantations test were developed since 2005 with different spacing and in different land use and soil types but the monitoring is not regular. To fight against this deficiency in term of silviculture, new plantations were established since 2010 by the national office of wood. To date different plantations types can be noticed in Dogo Ketou forest, Atcherigbe forest, Kilibo forest.

\subsection{Importance of Dry Zone Mahogany in National Plantations in Sudano-Guinean zone in Benin}

Mostly, national plantations are based on exotic species such as $T$. grandis and $G$ arborea. Considering the impact of such practices by combining local population needs, timber market and biodiversity loss, there is a challenge to integrate native species in such system. In this line, integration of Mahogany species was done in some plantations. The result of area used for mahogany plantation for a period of five year was show in the figure 4 . This result shows that Teak is still the most important species of ONAB plantations with the area increased significantly from 2010 to 2013, but Mahogany plantation started in 2010 with the small increased from 2012 to 2013.

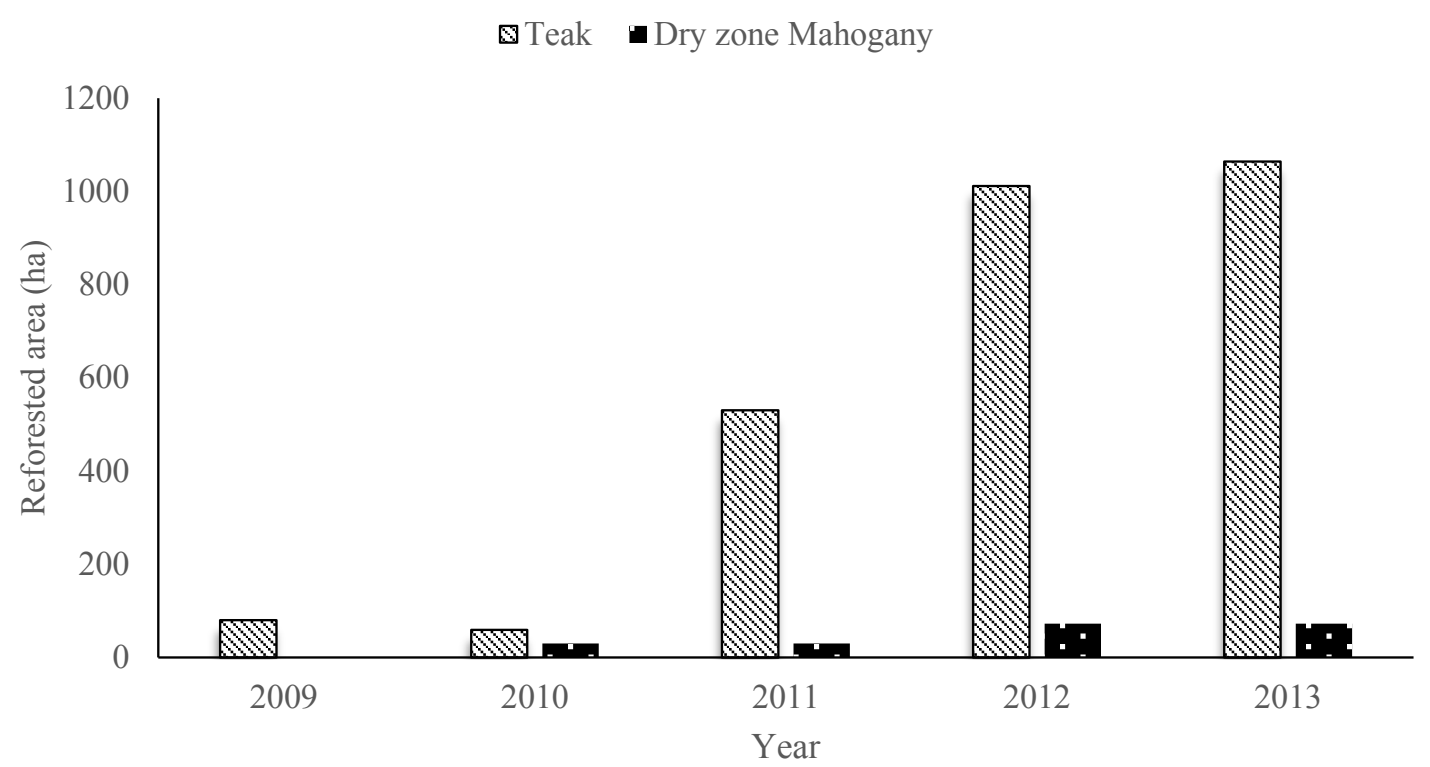

Figure 4. Comparison between Teak and Dry zone Mahogany in national plantations in Sudano-Guinean zone of Benin 

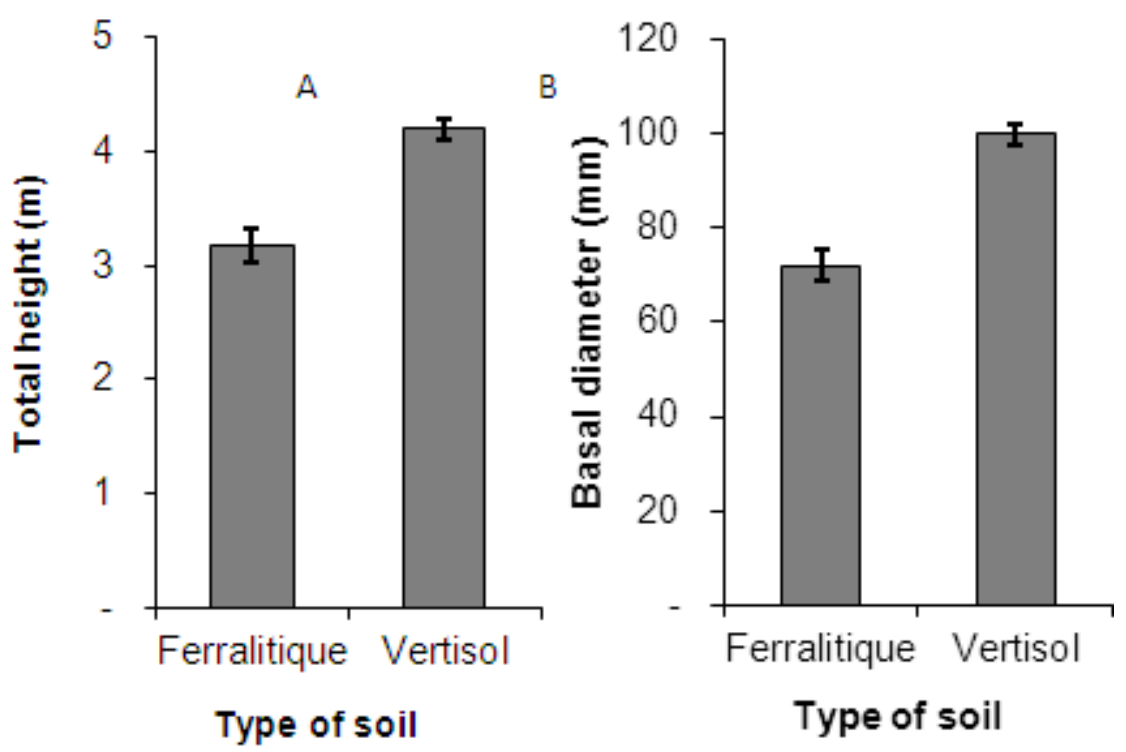

Figure 5. Error bar plot of $K$. senegalensis seedlings height and basal diameter on different soils

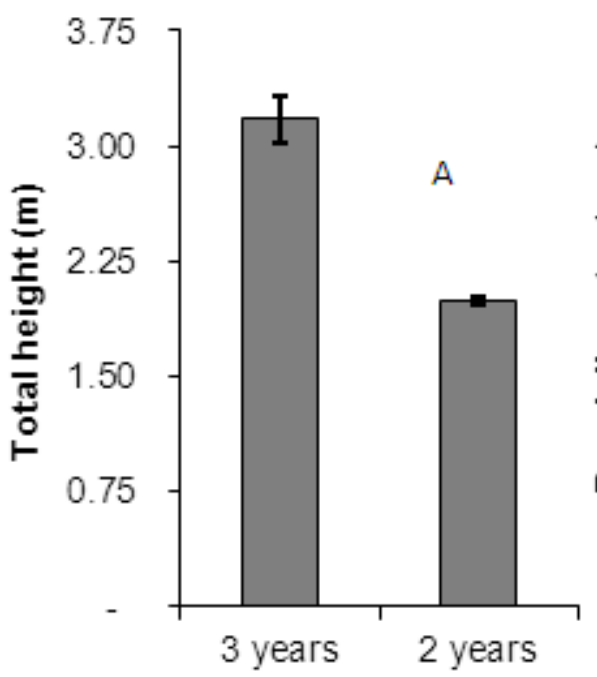

Age of the plantations

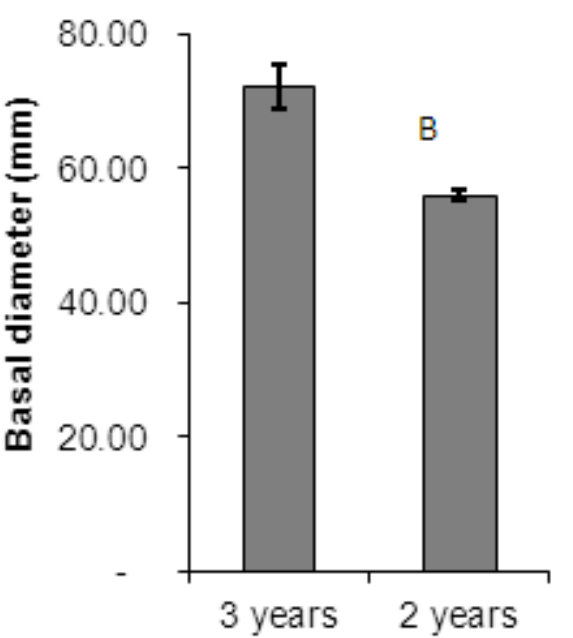

Age of the plantations

Figure 6. Error bar plot of K. senegalensis juvenile basal diameter (B) and Height (A) on different years

\subsection{Impact of Soil Types on Stand Structure of Khaya in Plantation}

The results of permutation test on students test showed that the soil does not influence neither the mahogany plantation basal diameter $(\mathrm{P}=0.090)$ nor their height $(\mathrm{P}=0.100)$. Nevertheless the bar plot (Figure 5) revealed that seedlings of the species had greater total height and basal area as compared to ferruginous soil. Overall, $32.25 \%$ of growth was recorded on vertisol than ferruginous soil for the total height and $38.75 \%$ of growth on vertisol than ferruginous soil for the basal diameter. Moreover, a density of $508 \pm 24$ trees/ha was recorded in plantations with the spacing of $4 \mathrm{~m} * 3 \mathrm{~m}$ in all plantations of the study area.

\section{Discussion}

\subsection{Current Status of Dry Zone Mahogany Resources}

This study was carried out to understand the monitoring of essays on the indigenous species Khaya in plantations. In the new policy of the forest administration in Benin, the behavior of Mahogany in plantation is important in order to link the population's needs conservation. To attend this goal agroforestry may be promoted with the integration of Mahogany in agroforestry system. According to Sokpon et Ouinsavi [26], 2002; Gaoue et Tincktin [16], 2009, damage on old plantations is high elsewhere in the country. To control this impact, the new plantations must be controlled by forest officer and any damage must be controlled. For the better management of Mahogany plantations in Benin, home garden with Khaya trees could be promoted. Planters could also benefit from the medicinal properties, in addition, will limit the harvesting on plantations and increase timber 
quality. Recent study on home gardens in Benin (Salako [26] et al. 2014) shows their potential contribution to conservation of threatened species like Khaya. In regards of the Benin situation of integration of indigenous species in large scale plantation, development of reforestation strategy at national level with priority and synergy actions by all stakeholders appear also as the best tool. For example in Ghana, this strategy was developed for a period of 25 years (Forest Commission [13], 2013). This strategy will help in the long-term monitoring of plantations and will help informed in the best technical production routes required (row spacing density, maintenance, thinning frequency, pruning, etc.) of indigenous and threatened species.

\subsection{Importance of Dry Zone Mahogany in National Plantations in Sudano-Guinean Zone in Benin}

The current findings showed that exotic species are well represented in plantations in Benin than indigenous ones. This is because exotic species plantations are established for timber market and few native species were integrated due to their slow growth rate. This result was confirmed through informal discussion with local populations in Benin in term of preference for reforestation. In addition, ONAB is a profit organization with economy based on timber trade (ONAB [20], 2014). According to that, species with fast growth are suitable. It was noticed that for the best integration of Mahogany species in large scale plantations, genetic improvement is required.

Our result showed also the integration of Mahogany in plantations but the surface considered remains very low to date. We noticed that the growth rate of Mahogany is not comparable with Teak and for the same author; many other factors influence the large propagation of Mahogany in plantations such as sylviculture technique for the good productivity, pest management, etc. According to (Ray Fremlin [22], 2012), genetic improvement could be the future of Khaya plantations. This means that identification of plus trees provenances with very good qualities are a first step of the selection. In One recent study conducted by (Akpona [5], 2013), the seeds used for reforestation in Benin are not always collected from the best genetic producers. In Benin, many sites are used for seeds collection but a few trees have very good characteristics. This can explain the behavior of trees in plantations and the success of its integration.

\subsection{Impact of Soil Type on Khaya Growth in Plantation in Benin}

This study shows that juvenile grow faster on vertisol than on ferruginous soil; however the soil type neither influence the mahogany plantation nor the basal diameter and their height. According to Robertson [23] et al. (2012), Khaya grows in a wide range of soil types but well- drained soils is prefers (Sokpon et Ouinsavi [26], 2002). It was recorded that density of plantation impact growth of KS and planting density can be increased to $5 \mathrm{~m} \times 3 \mathrm{~m}$ ( $666 \mathrm{stems} / \mathrm{ha}$ ), or even $4 \mathrm{~m} \mathrm{x} 3 \mathrm{~m}$ (833 stems/ha) for inferior seedlings and poorer soils (Robertson [23] et al. 2012). The density recorded with this study ( $308 \pm 24$ stems/ha) is low comparing to Robertson [23] et al. 2012, and can be explain by the mortality of seedlings due to the attack by shoot borer and external event (climate change, maintenance, etc.). The attack by boring insects and caterpillars was noticed by Sokpon et Ouinsavi [26] 2002. Previous study Opuni-Frimpong [11] et al. (2008) shows that severely attacked by shoot borers (Hypsipyla robusta) can negatively impact the timber value; however, the shoot borer operates in the Top End of the tree (Sokpon et Ouinsavi [26], 2002). Moreover, plantation cleaning is not regular but we do not notice human pressures and fire damage.

\section{Conclusion and Implications for Sustainable Management}

For the sustainable management of Dry zone mahogany in Benin, plantation can be established on various type of soils, sylvicultural management is suitable to improve it growth and to ensure the long term productivity of such plantations. The Sudano-guinean zone where such plantations are currently established is well drained and even if vertisol shows better growth rate, demand for agriculture can negatively impact the long term conservation on this soil type. Genetic improvement is required in the choice of seed by mapping the best genotype trees to be used in seed collection. Some study must be developing to map the good seed producers in wild and the habitat suitability for the future area of Mahogany plantations. Moreover, management actions are required such as plantations cleaning, protection against insect attack and diseases.

\section{Acknowledgements}

Financial support was provided by the International Tropical Timber Organization (ITTO) through ITTO Fellowship Ref. 227/14S provided to the first author. We thank ONAB administration who provided information about these plantations and allow the research in these sites.

\section{REFERENCES}

[1] Adjanohoun EJ, Ahyi MRA, Aké Assi L, Baniakina J, Chibon P, Doulou V, Enznza A, Eyme J, Goudote E, Guinko S, Keita A, Mbemba C, Mollet J, Moutsambote JM, Mpati J, Sita P. 1998. Médecine Traditionnelle et Pharmacopée: Contribution aux études ethnobotaniques et floristiques en République Populaire du Congo, ACCT, Paris

[2] Adomou C.A., Agbani O.P., Sinsin B. 2011. Plantes. Plants. In: Neuenschwander P.S., Sinsin B., Goergen G. (Eds.), Protection de la nature en Afrique de l'Ouest: Une liste rouge 
pour le Bénin. Nature Conservationin West Africa: Red List for Benin. International Institute of Tropical Agriculture, Ibadan, Nigeria, 365p.

[3] Agbahungba G., Sokpon N., Gaoué O. G., 2001. Situation des ressources génétiques forestières du Bénin. Note thématique sur les ressources génétiques forestières. Document FGR / 12F. Département des forêts, FAO, Rome, Italie, 39 p.

[4] Akoègninou A. and S. Lisowski. 2004. Un Ipomoea (Convolvulaceae) nouveau et un Thunbergia (Acanthaceae) nouveau du Bénin. Systematics and Geography of Plants, 74(2): 337-340

[5] Akpona, 2013. Strategies for sustainable management and conservation of mahogany in Benin: Case study of dry zone mahogany (Khaya senegalensis) in plantation. Oral presentation, International conference on "Towards sustainable production of Mahogany species in plantations in tropical Africa”, CSIR-FORG, Kumassi, Ghana

[6] Atawodi S. E., Ameh D. A., Ibrahim S., Andrew J. N., Nzelibe H. C., Onyike E. O., Anigo K. M., Abu E. A., James D. B., Njoku G. C., and Sallau A. B. 2002. Indigenous knowledge system for treatment of trypanosomiasis in Kaduna state of Nigeria. Journal of Ethnopharmacoly 79:279-282.

[7] Bonou W., Glèlè Kakaï R., Assogbadjo A. E., Fonton H. N. \& Sinsin B. (2009). Characterisation of Afzelia africana Sm. habitat in the Lama Forest reserve of Benin. Forest Ecology and Management, 258: 1084-1092.

[8] Djossa B.A., Fahr J., Wiegand T., Ayihouenou B.E., Kalko E.K., Sinsin B.A. (2008). Land use impact on Vitellaria paradoxa C.F. Gaerten. Stand structure and distribution patterns: a comparison of Biosphere Reserve of Pendjari in Atacora district in Benin. Agroforestry Systems, 72: 205-220

[9] Dalziel, J.M. (1937). The Useful Plants of West Tropical Africa. Grown agents for the colonies. London 612.

[10] DGFRN, 2012. Quatrième rapport national du Bénin sur la diversité biologique. UNDP, Benin 64p.

[11] Opuni-Frimpong E., Karnosky D.F., Storer A.J., Abeney E.A., Cobbinah J.R. 2008. Relative susceptibility of four species of African mahogany to the shoot borer Hypsipyla robusta (Lepidoptera: Pyralidae) in the moist semi deciduous forest of Ghana. Forest Ecology and Management, Volume 255, Issue 2, 10 March 2008, Pages 313-319

[12] Fao, 1999. Situation des forêts du monde. Rome, Italie, 154 p.

[13] FAO (2004). Rehabilitation of degraded lands in Sub-Saharan Africa: lessons from case studies. In: Workshop on strengthening regional action - implementation of the IPF/IFF proposals for action in Africa. Accra, Ghana: Food and Agriculture Organization of the United Nations.

[14] Forest Commission, 2013. Ghana Forest Plantation Strategy: $2015-2040,71 \mathrm{p}$

[15] Gaoue OG, Ticktin T (2007). Patterns of harvesting non-timber forest product from the multipurpose tree Khaya senegalensis in Benin: variation across climatic regions and its impacts on population structure. Biological Conservation,
$137,424-436$.

[16] Gaoue OG, Ticktin T (2009). Fulani knowledge of the ecological impacts of Khaya senegalensis (Meliaceae) foliage harvest in Benin and its implications for sustainable harvest. Economic Botany, 63, 256-270.

[17] Glèlè Kakaï R., Akpona T. J. D., Assogbadjo A. E., Gaoue O. G., Chakeredza S., Gnangle P. C., Mensah G. A., Sinsin B. (2011). Ecological adaptation of the shea butter tree (Vitellaria paradoxa C.F. Gaertn.) along climatic gradient in Benin, West Africa. African journal of ecology, 49:440-449.

[18] Joker D. \& Gamene, C.S. (2003). Khaya senegalensis (Desr.) A. Juss. In: Seed Leaflet. Denmark: Danida Forest Seed Centre.

[19] Manly, B. F. J. (1997). Randomization, Bootstrap and Monte Carlo Methods in Biology, 2nd ed. Chapman and Hall, London.

[20] Office National du Bois, 2014. Programme de reboisement à grande échelle: Acquis et perspectives. Oral presentation.

[21] Parren, M. P. E. 2003. Liana and logging in West Africa. PhD Thesis. Wageningen University, Wageningen, the Netherlands.

[22] Ray Fremlin, 2012, Genetic improvement is the future of African mahogany (Khaya senegalensis) plantations. Presentation to the IUFRO/FORNESSA Regional Congress.

[23] Robertson, B., \& Rilley, D. (2002). Growing African Mahogany in Northern Australia DBIRD Agnote 811 G25

[24] Salim, M.R., Othman, F., Imtiaj Ali, Md., Patterson, J., Hardy, T., 2002. Application of locally available materials for the treatment of organic polluted water. Water Sci. Technol. 46, 339-346.

[25] Sinsin, B., S. Oloulotan, and M. Oumorou. 1989. Les pâturages de saison sèche de la zone soudanienne du Nord-Est du Bénin (Dry season pasture in the Sudanian zone of the North East of Benin.). Revue Elevage et Médicine Véterinaire En Pays Tropicaux, 42:283-288.

[26] Sokpon, N., and C. Ouinsavi. 2002. Utilisations du Khaya senegalensis en médecine traditionnelle au Bénin. Revue de Médecine et Pharmacopée Africaine, 16:9-16.

[27] Salako V., K., Fandohan B., Kassa B., Assogbadjo A., E., Idohou A., F., R., Gbedomon R., C., Chakeredza S., Dulloo M., E., Glele Kakaï R. 2014. Home gardens: an assessment of their biodiversity and potential contribution to conservation of threatened species and crop wild relatives in Benin, Genetic Resources and Crop Evolution, 61:313-330.

[28] Wezel A. \& R. Böcker (2000): Vegetation of Benin. pp. 219 227, In: F. Graef, P. Lawrence \& M. von Oppen (eds.) Adapted farming in West Africa: Issues, Potential and Perspectives. Verlag Ulrich E. Grauer, Stuttgart. Williams, J.R. (1975): Sediment routing for agricultural watersheds. Water Resources Bulletin, 11(5): 965-974.

[29] Willaine P. and Volkoff B. 1967. Carte pédologique du Dahomey à l'échelle de 1/1000 000. Paris: ORSTOM. 